\section{Preconceptions of the Ideal: Ethnic and Physical Diversity Fashion}

Thomas Werner *

\begin{abstract}
As we see a rise in the conversation regarding diversity across social media, the fashion industry is simultaneously driving a discourse around inclusion and the preconceived ideas of the "ideal" and body diversity. What has been a predominantly Western European and American response will be examined via current advertising campaigns and runway shows hosted by established fashion companies, (e.g. Gucci, Max Mara, Bottega Veneta, Aerie, Rio Uribe, and others) providing context for the socio-cultural evolution within the fashion industry.
\end{abstract}

Keywords: Diversity - Fashion Campaigns - Cultural - Cross-Cultural - Advertising Campaigns - Media - Commercial Media - Social Awareness - Mono-ethnic.

[Abstracts in spanish and portuguese on page 193]

(*) Thomas Werner is the author of the book The Fashion Image for Bloomsbury Press, London, and an Editor at Large for IRKmagazine, a Paris based fashion and culture magazine and web site. An Assistant Professor and past Photography Program Director at Parsons School of Design in New York, Thomas currently lectures internationally on topics of photography, fashion, education, and contemporary professional practices. He is also the former owner of Thomas Werner Gallery in Manhattan's Chelsea Art District, and recently lead a team developing a media and literacy web site and resource center in five languages, Spanish, French, Russian, Arabic and English for the United Nations Alliance of Civilizations/UNESCO. Werner has worked with the Department of State on cultural projects in Russia, and been a photography consultant for $\mathrm{COACH}$ and Rodale Publishing, among others. He has been a recurrent instructor at the United Nations Education First Summer School, and is presenting workshops on effective message development and visual communication on an international basis.

Over the last 12 years his research work has been Russia centric spending an average of 40 days a year there partnering with 32 cultural, educational, and governmental organizations to develop projects in 29 cities. The focus has been the introduction of contemporary education methodologies, and the development of creative cultures within the country. Russian partners have included; The State Hermitage Museum, the National Center of Contemporary Art, Perm Regional Government, The Moscow Biennale for Young Art, National Centre of Photography for the Russian Federation, The Central State Archive of Film, Photographic and Phonographic Documents, The Pro Arte Foundation, and others. He has curated exhibitions in the United States and abroad, including seven co-curated 
exhibitions at the State Hermitage Museum in Saint Petersburg, Russia. His private collection of Russian photographs and artifacts, have been exhibited internationally.

\section{Introduction}

Historically, fashion design -and the imagery that defines it- has shown us where our boundaries lie and how we alternately seek to embrace or break them. This applies not only to the garments we wear, but also to the manner in which fashion addresses the social and cultural norms of the era or country in which they are designed, presented, and advertised. As noted by Contributing Editor to Vogue Camilla Nickerson, in the motion picture In Vogue, "Fashion to me is a reflection of culture. It is not just about whether everyone's wearing a trench coat, it's a report on the world at large" (as cite in Bailey\& Barbato, 2012). According to the illustrations in the Western European and American fashion magazines and the runways prior to 1959, the world of fashion was solely Caucasian. Additionally, although the body types shown in fashion have ranged dramatically from the early $1900 \mathrm{~s}$ to present, a broader inclusion of body diversity is new to both the Western European and American fashion industries.

The recent study "Comparative Analysis of Media's Portrayal on Ethnicity and Diversity for Fashion Magazine Covers" held at Illinois Sate University investigated how fashion magazine covers portray American beauty ideals with regards to ethnic diversity and thinness in fashion magazines. Content analysis was conducted using 60 covers collected from American Vogue and 60 covers from Gentleman's Quarterly (GQ) over the past six decades, beginning with February 1957. Results showed that of the 78 female models depicted on the Vogue covers, a mere 5.13 percent were Black, while 94.87 percent of the models were Caucasian. The Gentleman's Quarterly covers featured a total of 63 male models of whom 88.88\% were Caucasian, 9.52 percent African American, and 1.60 percent Latino. A total of 12 female models (6.5\%) portrayed on the Gentleman's Quarterly covers were categorized as Caucasian. Overall, the male models in Gentleman's Quarterly represented more ethnicities than female models in both Vogue and Gentleman's Quarterly combined (Lauf, Willer, Wetzel, Campbell, \& Yu, n.d.).

The study suggests the statistical representation of non-Caucasians in fashion media does not reflect the statistics of the nation's population. When compared to the 2016 U.S. Census estimate that showed 76.9 percent of the US population was represented as Caucasian, 13.3 percent Black or African American, 1.3 percent American Indian, 5.7 percent Asian, and 17.6 percent Hispanic, we see the quantities of minorities underrepresented on the covers of American Vogue and Gentleman's Quarterly. It is important to note the 1960 U.S. Census -the first Census to include forms sent by mail (and therefore more accurate than previous accountings)- found 88.6 percent of the U.S. population was represented as Caucasian, 10.5 percent Black or African American, .3 percent American Indian, .5 percent Asian and Pacific Islander, and 3.2 percent Hispanic (U.S. Census Bureau, 1960). The Illinois State study does not take this variance into account; though when doing so, we still find a large disparity between minority populations and their representation on these magazines' covers. 
Given the Western fashion industry's “ideal” woman has been predominantly Caucasian, it is not surprising that the first non-Caucasian model did not grace the cover a major American fashion magazine until 1959 when Portuguese-American model China Machado appeared on the cover of the February issue of Harper's Bazaar. Interviewed in 2012, Machado spoke of her childhood in Shanghai, "We [non-whites] had no images. We had nothing that told us we were nice-looking. Nothing. So, I didn't think of myself as goodlooking at all. It never occurred to me" (as cited in Hoskins, 2014, p. 129). It wasn't until 1965 that Donyale Luna was featured as the first Black model on the cover of a major American fashion magazine when Harper's Bazaar Editor Nancy White featured an illustration of Luna on the January edition. Luna was quickly offered a one-year contract with the magazine, and in 1965 she was featured in a ground-breaking 6-page spread photographed by Richard Avedon (Arogundade, 2012). This was followed by Luna's appearance as the first black model on cover of British Vogue in March of 1966, and a biographic article in Time Magazine's April $1^{\text {st }}$ issue in 1966. Yet, despite these breakthroughs and the multi-cultural dialog of acceptance being promoted by the counterculture movement -as embodied in Coca Cola's groundbreaking "I'd Like To Teach The World To Sing" television advertising campaign in 1971 that featured ethnically diverse young people from around the world- the fashion runways continued to be dominated by Caucasian models.

The brief but acclaimed exception was in 1973 when "The Battle of Versailles" runway competition pitted five prominent American designers (Halston, Oscar de la Renta, Bill Blass, Anne Klein, and Stephen Burrows) against five of the most internationally esteemed French designers (Yves Saint Laurent, Hubert de Givenchy, Emanuel Ungaro, Pierre Cardin, and Marc Bohan of Christian Dior). This was a ground-breaking event for the American designers who had long been considered "second tier" up until that time; however, the American designers stole the show and left with a new-found respect amongst international fashion industry pundits. The event was particularly notable for the ethnic diversity of the fashion models. The American designers brought thirty-six models with them, eleven of whom were black -a relatively high number at the time. Their appearance on the runway at Versailles was a reflection of what was occurring politically and socially in terms of American race relations at home (Bateman2015).

Though symbolic of the Civil Rights Movement and the effort to create a society that was more inclusive, "The Battle of Versailles" was more spectacle than social change, and the inclusion of minority models post-Versailles remained inconsistent. In August of 1974, Beverly Johnson became the first black model to appear on the cover of American Vogue, with the covers of French Elle, Vogue Italia, and other publications and runways to follow. Throughout the late the 1970s Johnson, Iman, and Pat Cleveland appeared in a number of publications, though they were the exception rather than the rule. Vogue Paris continued to be dominated by Caucasian models until as late as 1988 when Yves Saint Laurent threatened to sever ties with the magazine unless Naomi Campbell was put on its cover (Hoskins, 2014).

The 1990s saw the emergence of hip hop and its influence on fashion and the broader cultural landscape. With his oversized preppy style, designer Tommy Hilfiger's fashions became a fixture in hip hop culture with Black artists like Snoop Dogg, Puffy, L'il Kim, and Usher wearing his clothes, and singer Aaliyah featured in his campaigns. Hilfiger recalls: 
In the late 1980s/early 1990s, my clothes were adopted by the music stars of that time -the rappers. They took the preppy style on board, but exaggerated it by blowing up the logo and wearing their chinos two sizes bigger (...). Snoop Doggy Dog appeared on Saturday Night Live wearing an oversized sweater of mine, again helping create a cult following for my label. I was even mentioned in some of the rappers' songs, which is a great honour for me (as cited in The Irish Times, 2000).

Hip hop "opened the door" for Black rap artists to appear in Hilfiger's advertisements. Black-owned companies, such as Damon John's FUBU (or, "For Us, By Us"), also featured rap music artists including LL Cool J along with minority-centric groups of young people in their campaigns, thus helping to diversify ethnic representation in the fashion design and editorial fields. Kimora Lee Simmons, former wife of rap singer Russell Simmons, has been a leading supporter of diversity on the runway. Of all the Fall 2017 runway shows held in New York, London, Paris or Milan that included at least one non-Caucasian model, both Kimora Lee Simmons and Kayne West's brand "Yeezy" ranked in the top 5 for featuring racial diversity among their models (Safronova, 2017). In another breakthrough for the runway, Max Mara's Fall 2017 runway show featured the model Halima Aden in a hijab, further contributing another step towards diversification.

Despite these advances, there are still challenges in terms of promoting racial diversity in the fashion industry. Many established, progressive brands continue to underrepresent diversity among their runway and/or editorial models. For example, the Italian house Prada did not feature a Black model in its advertising campaigns for 19 years until Malaika Firth was cast in 2013. Before this, the last Black model to be featured in a Prada campaign was Naomi Campbell in 1994, the year Firth was born. Following her appointment in 2009, Céline's Creative Director Phoebe Philo didn't use any Black models in the company's runway shows until Spring/Summer 2014 (Stoppard, 2016).

These brands are not an anomaly. Every season, the fashion blog Jezebel calculates the percentage of Caucasian models -compared to non-Caucasian models-featured on the runways of New York Fashion Week. In Fall of 2013, the statistics listed by Jezebel were: 79.98\% white, $8.08 \%$ Black, $8.1 \%$ Asian, 3.19\% Latina. That same season, the demographics of the four major fashion week runways (New York, London, Milan, and Paris), featured close to 88\% Caucasian models (Padula, 2015). While the statistics for the Fall $2013 \mathrm{New}$ York runways moved closer to the demographics reported in the U.S. 2016 Census, there were still disparities when it came to Black, and particularly Latina, models. Asian models were over-represented when compared to the U.S. 2016 Census, though still substantively underrepresented when viewed as a percentage of the population internationally. Underrepresentation of non-Caucasian populations on the runway increases substantially when all four major fashion centers (New York, Paris, London and Milan) are considered. This underrepresentation is being increasingly addressed. In her article, "Whitewashed Runways: Employment Discrimination in the Fashion Modeling Industry," Vanessa Padula (2015) states: 
Some believe that there are economic reasons behind the industry's discriminatory casting practices. While 'it used to be about fashion,' it has turned into being 'about business.' This argument is based on the idea that models of color are not hired more because 'black don't sell.' The more prevalent argument, however, appears to be that in fashion, race is viewed as any other aesthetic feature, such as hair and eye color. For example, when Alber Elbaz, a designer for Lanvin, presented five black women walking down the runway together as the finale for his show, it was described as 'purely aesthetic' (n.p.).

Fashion models Naomi Campbell and Iman, together with campaigner Bethann Hardison, disagreed with the aesthetic argument for predominantly Caucasian advertising and runways, as they wrote in an open letter to designers in September 2013: "No matter the intention, the result is racism" (as cite in Hoskins, 2014, p. 134).

\section{The 2017 Season on the Runway}

The Fall of 2017 provided substantial improvement in terms of ethnicity on the runway, particularly in the three European fashion centers (Paris, Milan, and London). Each fashion season, theFashionSpot creates theFashionSpot Runway Diversity Report that provides the ethnic breakdown for each designer's runway, as well as the overall numbers for each city and the fashion shows as a whole. Recently, the report (2017) stated:

[For the] Fall 2017 season, we examined 241 shows and 7,035 model castings from New York, London, Paris and Milan. According to our data, more women of color walked the runway than ever before. For all four cities combined, 72.1 percent of the models cast were white and 27.9 percent were women of color. This represents a 2.5-point increase over the 25.4 percent nonwhite models we reported for Spring 2017. For reference, Fall and Spring 2016's runways were 24.7 and 22.4 percent nonwhite, respectively (n.p.).

The report also stated that Paris, London, and Milan all saw their most diverse fashion season ever, with New York still presenting the most diverse runways with 31.5 percent models who were non-Caucasian, just .4 percentage points below its most diverse season in Fall 2016. Moreover, for the first time, every runway show in Manhattan included at least one non-Caucasian model. London was second with 27.5 percent, a 4.9 percent increase over Spring 2017. London was followed by Paris and Milan with 25.9 and 23.8 percent respectively; though lagging in diversity, both cities have seen annual improvements since Spring 2015.

While there are significant inequities in terms of racial diversity, a number of brands are promoting diversity. During Paris Fashion Week in 2016, Balmain stood out as an example of a fashion brand that embraced its global audience as each model was of a different in heritage and ethnicity (Stoppard, 2016). During the Fall 2017 fashion shows, the most progressive designers included Rio Uribe who featured 87 percent models of color on the 
runway, Chromat (77 percent), Kimora Lee Simmons (75 percent -down from 85 percent in Spring 2017), and Kanye West (74 percent -down from 97 percent last season and 100 percent the prior season). Conversely, some designers continue to show predominantly Caucasian models. These designers and houses include Lavin where 15 percent of the models on the runway were non-Caucasian, and at Balenciaga (26 percent). Undercover, Trussardi and Junya Watanabe presented entirely Caucasian shows, while Comme des Garcons, Chocheng and Wuachob each cast just one non-Caucasian model (theFashionSpot, 2017).

The men's wear collections added another dimension of diversity to the runway with older models featured in a number of fashion shows - a still rare occurrence in women's wear (Stoppard, 2016). That said, there were Spring 2016 runways that featured women in their thirties and above. For example, in New York, the fashion house Eckhaus Latta featured art adviser Thea Westreich and television producer Susan Fales-Hill; designer Tracy Reese included artist Susan Cianciolo and 1990s iconic fashion model Coco Mitchell; designer Son Jung Wan featured 1960s "supermodel" Pat Cleveland; and J. Crew's fashion show featured staff, family, and friends that represented a large span of age groups. In Italy, Lauren Hutton modeled for the house Bottega Veneta, yet Parisian designers did not participate in this trend (Tai, 2016). This was a small but important step towards true diversity during fashion week.

\section{The 2017 Season in Advertising Campaigns}

Over the last two years, a number of leading fashion brands have made an effort to diversify the fashion models used in their advertising campaigns -though at times with mixed response. For example, Gucci featured (as part of the brand's 2017 pre-fall campaign) a series of Instagram videos in which it asked Black models, "What does it mean to have soul?". The campaign, titled "Soul Scene," was photographed to look like a late 1960's or early 1970's block party. This was a step forward for Gucci whose past campaigns had featured predominantly Caucasian models. Yet, questions regarding its authenticity were raised by some. As R. Eric Thomas (2017) notes in The New York Times:

While the campaign purports to celebrate black soul, it smacks of performance rather than genuine homage. Is it offensive? Not really. Is it appropriation? Well, there's the rub. It would be if the ads included the culture. Instead, Gucci presents a reverent, painstakingly-recreated facsimile of a culture. More than anything, the campaign is about the look (n.p.).

Several fashion brands have also supported ethnic diversity in their recent advertising campaigns. Designer Brandon Maxwell featured Black model Jourdan Dunn and her son in his Spring/Summer 2018 advertising campaign and has featured diverse models since his brand's first campaign in Fall of 2016. Acne Studios' Fall 2017 campaign -featuring Kordale Lewis and Kaleb Anthony, a gay Black couple, and the gentlemen's four children- was considered by many to be history-making as they became the first Black LGBT 
(Lesbian, Gay, Bisexual, and Transgender) family to represent a "high-fashion" European clothing line (Payne, 2017).

These, and other advertising campaigns, contribute towards the growing diversification of models' ethnicities within the fashion industry. This is suggested by theFashionSpot's 2017 Diversity Report -a review of 187 advertisements and 487 castings- that showed an overall increase in diversity in the advertising campaigns that exceeded the gains on the runway. The study notes 30.4 percent of the models featured in advertising campaigns were nonCaucasian, almost double the 15.3 percent featured in Spring of 2015. This represented the highest total recorded and a 5.9 percent increase over Spring 2017 (Tai, 2017).

\section{Women's Body Diversity}

Ethnicity was not the only area in which the fashion industry expanded models' diversification over the past two seasons; plus-size models increased their presence on the runway -yet seem to have plateaued in terms of advertising campaigns. Valeriya Safrona (2017), writer for The New York Times stated in her article "Diversity, of All Kinds, Is on the Rise at Fashion Shows," thirty plus-size models walked the runways that season, up from sixteen last season and six the season before, though most of the appearances were in New York. Ashley Graham -who is becoming something of a "supermodel," with history-making appearances on the covers of the Sports Illustrated Swimsuit Issue, British Vogue and American Vogue- became the first plus-size model to walk in a Michael Kors show, though she was also the only plus-size model in the show (Safronova, 2017). TheFashionSpot's Diversity Report noted the 2017 fashion season was something of a watershed moment for the fashion industry; yet, in the print advertising domain, plus-size women accounted for just 10 of the 457 model castings -or, 2.2 percent, a 0.1-point dip from the Spring 2017 campaign season. The low number of plus-size castings demonstrates that fashion designers still have a long way to go in terms of inclusion (Tai, 2017).

However, there were positive signs in commercial advertising that went beyond the few, popular models like Ashley Graham. The lingerie and intimate apparel brand Aerie has consistently used models of various races and body types in its print and video advertising. The company's recent advertising campaign featured a diverse group of models (dubbed the “@aerieReal Role Models") including singer/songwriter Rachel Platten, actress Yara Shahidi, gold medal winning gymnast Aly Raisman, and body positive activist Iskra Lawrence. This is a notable example of a fashion company that has placed positive body image at the core of its brand identity. Additional examples of advertising campaigns featuring body diversity include plus-size model Candice Huffine appearing in bikini advertisements for Violeta by Mango, and models Philomena Kwao and 56-year-old Nicola Griffin, joining Ashley Graham in a 2016 campaign for Swimsuitsforall. In addition to being socially responsible, the inclusion of plus-size models is a good business decision for many designers. According to The NPD Group, a New York-based market research company, annual U.S. sales of women's plus-size apparel (sizes 14 and higher) rose by 17 percent to $\$ 20.4$ billion in 2016, from $\$ 17.4$ billion in 2013. During that time, overall apparel sales increased by just 7 percent (The Fashion Law, 2017). 


\section{Men's Body Diversity}

Men faced similar issues regarding physical diversity on the runway and in fashion advertising campaigns. In his article "Expanding the Male Ideal: The Need for Diversity in Men's Fashion Advertisements," Ben Barry (2014) describes the two body types that have dominated men's fashion over the past thirty-five years. Barry's research found that male models in men's magazines depict a relatively uniform hegemonic, muscular body type and that the presence of muscular male models has increased over time in popular men's magazines. However, the idealized male body has evolved in the fashion industry. When designer Hedi Slimane introduced a skinny male silhouette for Dior Homme with great fanfare in 2000, a new male body standard emerged. This slimmer body gained tremendous attention and widespread appeal, thus prompting the Rootstein male mannequin -the fashion industry's "golden standard"- to shrink from a 42-inch chest and 33-inch waist in 1967 to a 35-inch chest and 27-inch waist in 2010. The garment sample size for male models also decreased from an Italian suit size 50 (U.S. 40) in the 1990s to a size 46 (U.S. 36) today (Barry, 2014). This has provided two rather unattainable physical choices for the majority of men. As note earlier, there may be greater age diversity on the men's runways, but this area of the industry lags behind women's wear in terms of diverse physical representation. Overall, there has been minimal dialog regarding ethnic or physical diversity in men's fashion. At this point in time, the conversation surrounding women has yet to expand to men.

\section{Legal Changes}

Concerns regarding the homogeneous, and at times, unhealthy body types represented on the fashion runway have also caught the attention of government officials. In 2017, France passed a law requiring models to provide a doctor's certificate attesting to their overall physical health, with special regard to their age and body mass index (BMI), a measure of weight in relation to height. Employers breaking this law could face fines of up to 75,000 Euros $(\mathfrak{E} 63,500 ; \$ 82,000)$ and up to six months in jail. The French Ministry of Health has stated the aim is to fight eating disorders and inaccessible ideals of beauty (BBC News, 2017). Eleven years earlier, Spain passed a law banning models with a body mass lower than 18; the United Nations recommends a body mass of between 18.5 and 25 for healthy individuals (BBC News, 2006). The year 2006 also saw Italy ban female models with a BMI of less than 18.5. Other legislation enacted by government officials included a minimum age limit of 16 for models and a ban on using cosmetics to achieve an 'anorexic look' with dark shadows under the eyes (McMahon, 2006). In the U.S., The Council of Fashion Designers of America (CFDA) has opted instead for voluntary measures that put the focus on nutritional and emotional counseling. According to CFDA President Diane von Furstenberg, some models have been "red-flagged" and removed from the runway to focus on eating and living well (as cited in Critchell, 2010).

The concerns regarding body representation and good health have not ended on the runway. In October of 2017 France enacted a law that requires all commercial photos that have been digitally altered to make a model's body appear thinner or thicker to bear the 
warning "photographie retouchée" (retouched photograph). Those who do not comply with this law face a fine of at least $\$ 44,000$ USD, or 30 percent of advertising costs. According to Delphine Perez, writing for Le Parisien, Marisol Touraine, France's former health minister, got the ball rolling on the idea of the law and explained, "It is necessary to act on body image in society to avoid the promotion of inaccessible beauty ideals and prevent anorexia among young people" (as cited in Yee, 2017).

One of the problems models face is a lack of legal protection. In most countries, models are considered independent contractors -and this comes with certain implications. In the U.S., each state has a different common law standard for distinguishing independent contractors from employees, and models in the U.S. are still considered independent contractors, having "commission-based contracts" with their agencies. Under Title VII, an employer cannot discriminate against an employee based on religion, sex, national origin, race, or color. Discriminatory practices covered by the statute include: refusing to hire or promote an employee; firing an employee; or segregating or classifying an employee based on any of the attributes listed above. In order for an employee to establish a case of employment discrimination under Title VII, they must provide evidence that the classification was a "motivating factor" in a decision made by their employer that adversely affected them. In the case of fashion models, the model would have to demonstrate that the color of his/her skin motivated the casting director or designer to not hire them.

In this context, it is important to consider the argument that designers and casting directors engage in artistic expression when casting models for their fashion shows and campaigns. In deciding which models to cast, many designers and casting directors strive to captivate the creative vision that inspired the fashion collection. Thus, a model may not be hired because she is not what the designer "aesthetically and artistically" envisioned. Although this First Amendment claim may disparately affect non-Caucasian over Caucasian models, it appears that some courts would agree with protecting this type of artistic expression. The Supreme Court concluded that the motion picture industry is afforded a similar protection under the First Amendment. It is possible many fashion designers use similar reasoning to argue that it is their First Amendment right to cast the models they wish for their fashion shows and/or advertising campaigns (Padula, 2015).

\section{Conclusion}

The increasing demand and necessity for ethnic, age-based, and body diversity on the runway and in advertising is changing the manner in which fashion designers and brands cast and produce fashion shows and advertising campaigns. These changes to the existing fashion system are essential, not only in terms of meeting societal demand, but also to address the promotion of unhealthy body types. In the rapidly changing commercial environment, outdated business practices must evolve to reflect the broader community. Although the 2016 and 2017 runway shows and advertising campaigns showed marked improvements in showcasing diversity, deficiencies remain. However, if the recent fashion seasons suggest an ongoing increase of diversity in the fashion industry -particularly in 
the U.S. and specifically New York- fashion companies and advertising agencies will better reflect the demographics of their potential clientele and the countries in which they reside.

\section{References}

Arogundade, B. (2012, November 11). The tragic tale of Donyale Luna. The Telegraph Media Group. Retrieved from http://fashion.telegraph.co.uk/news-features/TMG9658276/ The-tragic-tale-of-Donyale-Luna.html

BBC News. (2006, September 13). Madrid bans waifs from catwalks. The British Broadcasting Corporation. Retrieved from news.bbc.co.uk/2/hi/ $5341202 . s t m$

BBC News. (2017, May 6). France bans extremely thin models. The British Broadcasting Corporation. Retrieved from http://www.bbc.com/news/world-europe-39821036

Bailey, F. \& Barbato, R. (Producers \& Directors). (2012). In Vogue: The editor's eye [Motion picture]. U.S.A.: Home Box Office Documentary Films.

Barry, B. (2014). Expanding the male ideal: The need for diversity in men's fashion advertisements. Critical Studies in Men's Fashion, 1(3). Bristol, UK: Intellect Ltd.

Bateman, K. (2015, July 2015). Versailles 1973: How one show changed American fashion history. Harper's Bazaar. Retrieved from https://www.harpersbazaar.com/fashion/design ers/a11385/versailles-french-american-fashion-show/

Critchell, S. (2010, February 13). Would older models quell too-skinny debate? The Boston Globe. Retrieved from http://archive.boston.com/lifestyle/fashion/articles/2010/02/10/ would_older_models_quell_too_skinny_debate/

Hoskins, T.E. (2014). Stitched up: The anti-capitalist book of fashion book. London, UK: Pluto Press.

The Irish Times. (2000, August 14). Say goodbye to hip-hop, it's time to get hip. The Irish Times. Retrieve from https://www.irishtimes.com/say-goodbye-to-hip-hop-it-s-timeto-get-hip-1.302650? mode=print\&ot=example.AjaxPageLayout.ot

Lauf, A., Willer, M., Wetzel, S., Campbell, J., Yu, U.J. (PDF document). Comparative analysis of media's portrayal on ethnicity and diversity for fashion magazine covers. Retrieved from https://www.audielauf.com/uploads/4/9/8/5/49858745/2017_aafcs_ethnic_diver sity_and_thinness_in_fashion_magaine_covers_2_.pdf

McMahon, B. (2006, December 2). Catwalk ban on the skinny model in Italy. The Guardian. Retrieved from https://www.theguardian.com/world/2006/dec/03/italy.barbaramcmahon

Padula, V. (2015). Whitewashed runways: Employment discrimination in the fashion modeling industry. Berkeley Journal of African American Law and Policy, 17(1). Retrieved from https://scholarship.law.berkeley.edu/cgi/viewcontent.cgi?article $=1177 \&$ context $=$ bjalp

Payne, T. (2017, August 18). Acne Studios campaign celebrates gay, Black dads. Teen Vogue. Retrieved from https://www.teenvogue.com/story/gay-black-dads-acne-studios-campaign

Safronova, V. (2017, March 16). Diversity, of all kinds, is on the rise at fashion shows. The New York Times. Retrieved from https://www.nytimes.com/2017/03/16/fashion/newyork-fashion-week-2017-diversity.html

Stoppard, L. (2016, July 26). How diversity changed fashion. ELLE. Retrieved from http:// www.elleuk.com/fashion/trends/longform/a31200/diversity-in-fashion/ 
Tai, C. (2016, October 14). Report: The Spring 2017 Runways Were the Most Diverse in History - sort of. theFashionSpot. Retrieved from http://www.thefashionspot.com/runway -news/717823-diversity-report-spring-2017-runways/

Tai, C. (2017, August 29). Diversity report: The Fall 2017 ads were more inclusive than the runways for the first time ever. theFashionSpot. Retrieved from http://www.thefashionspot. com/runway-news/762095-diversity-report-fall-2017-ad-campaigns/

The Fashion Law. (2017, February 28). Is the fashion industry actually starting to celebrate body diversity? The Fashion Law. Retrieved from http://www.thefashionlaw.com/home/ is-the-fashion-industry-actually-starting-to-celebrate-body-diversity

theFashionSpot. (2017, March 16). Report: Fall 2017 was a banner season for runway diversity, especially in New York. TotallyHer Media. Retrieved from http://www.thefashionspot. com/runway-news/740117-runway-diversity-report-fall-2017/

Thomas, R. E. (2017, April 17). Gucci's diversity drag. The New York Times. Retrieved from https://www.nytimes.com/2017/04/17/fashion/gucci-black-models-diversity.html

Lee, B. Y. (2017, October 1). New French law requires label for digitally altered photos of models. Forbes. Retrieved from https://www.forbes.com/sites/brucelee/2017/10/01/ new-french-law-requires-label-for-digitally-altered-photos-of-models/\#19c3ecaele0e

Resumen: A medida que aumenta la discusión con respecto a la diversidad a través de las redes sociales, la industria de la moda está impulsando simultáneamente un discurso sobre la inclusión y las ideas preconcebidas de lo "ideal" y la diversidad corporal. Lo que ha sido una respuesta predominantemente de Europa occidental y Estados Unidos, se examinará a través de campañas de publicidad actuales y desfiles organizados por compañías de moda establecidas (por ejemplo, Gucci, Max Mara, Bottega Veneta, Aerie, Rio Uribe y otros) que proporcionan contexto para la evolución sociocultural en la industria de la moda.

Palabras clave: Diversidad - Campañas de moda - Cultural - Transcultural - Campañas publicitarias - Medios - Medios comerciales - Conciencia social - Monoétnico.

Resumo: À medida que a discussão sobre a diversidade aumenta através das redes sociais, a indústria da moda está dirigindo simultaneamente um discurso sobre inclusão e idéias preconcebidas da diversidade "ideal" e corporal. O que tem sido uma resposta predominantemente da Europa Ocidental e dos Estados Unidos, será examinado por meio de campanhas publicitárias e desfiles organizados por empresas de moda estabelecidas (por exemplo, Gucci, Max Mara, Bottega Veneta, Aerie, Rio Uribe e outras). que fornecem contexto para a evolução sociocultural na indústria da moda.

Palavras-chave: Diversidade - Campanhas de moda - Cultural - Cross-cultural - Campanhas publicitárias - Mídia - Mídia comercial - Consciência social - Mono-étnica.

[Las traducciones de los abstracts fueron supervisadas por el autor de cada artículo] 